\title{
Depositional Model, Pebble Provenance and Possible Reservoir Potential of Cretaceous Conglomerates: Example from the Southern Slope of Medvednica Mt. (Northern Croatia)
}

\author{
Jasenka Sremac $^{1, * \mathbb{D}}$, Josipa Velić ${ }^{2}$, Marija Bošnjak ${ }^{3}$, Ivo Velić ${ }^{4,5}$, Davor Kudrnovski $^{1}$ \\ and Tamara Troskot-Čorbić ${ }^{6}$ \\ 1 Faculty of Science, University of Zagreb, Horvatovac 102a, 10000 Zagreb, Croatia; dkudrno@gfz.hr \\ 2 Faculty of Mining, Geology and Petroleum Engineering, University of Zagreb, Pierottijeva 6, 10000 Zagreb, Croatia; \\ josipa.velic@oblak.rgn.hr \\ 3 Croatian Natural History Museum, Demetrova 1, 10000 Zagreb, Croatia; marija.bosnjak@hpm.hr \\ 4 Croatian Geological Summer School, Pančićeva 5, 10000 Zagreb, Croatia; ivo.velic@zg.t-com.hr \\ 5 Croatian Geological Survey, Sachsova 2, 10000 Zagreb, Croatia \\ 6 INA-Industrija Nafte, d.d., Exploration \& Production, Exploration \& Upstream Portfolio Development, \\ Rock \& Fluid Analysis, Lovinčićeva 4, 10000 Zagreb, Croatia; Tamara.Troskot-Corbic@ina.hr \\ * Correspondence: jsremac@geol.pmf.hr; Tel.: +385-1-460-6108
}

Received: 15 September 2018; Accepted: 1 December 2018; Published: 4 December 2018

\begin{abstract}
Upper Cretaceous deposits in Medvednica Mt. are composed of coarse-grained conglomerates, sandstones, shales and the pelagic Scaglia Limestones. Such deposits in the wider region possess reservoir potential, not previously studied in Northern Croatia. Modal composition of conglomerates, size and distribution of clasts, porosity and permeability were studied from one new exposure in Medvednica Mt., and the results were compared with previously published data from neighboring successions. Conglomerates are polymictic, clast- to matrix-supported, with clasts and matrix entirely composed of local bedrocks. Porosity varies between 4.98 to $10.89 \%$ and permeability from 1.13 to $43.3 \mathrm{mD}$. Overlying pelagic Scaglia Limestones contain pelagic foraminifera of the latest Santonian to Early Campanian age ( 83 to $85 \mathrm{Ma}$ ). Clasts were eroded from the local hinterland, probably transported to the beach by short-term torrents and deposited along the shelves of the proto-Medvednica Island. Previously presumed alluvial transport is not likely. Deposition took place in a Gosau-type basin during the subsidence phase, additionally controlled by a third-order sea-level change at the Santonian-Campanian boundary. According to this study, Upper Cretaceous clastites possess possible reservoir potential, and deserve more attention in future hydrocarbon research in Croatia.
\end{abstract}

Keywords: conglomerates; Scaglia limestone; Gosau-type; Late Cretaceous; sedimentology; petroleum geology; statistics; northern Croatia

\section{Introduction}

Cretaceous deposits from the Medvednica Mt. have been studied since the beginning of the 20th century [1-5], in some cases as stops in field guides [6-8] or within unpublished doctoral and master theses, e.g., [9-11].

Polymictic conglomerates within the Late Cretaceous succession are composed of clasts of local origin $[4,7,8,10]$. Conglomerates in northwestern (NW) parts of the Medvednica Mt. transgressively overlie a Jurassic-earliest Cretaceous ophiolitic mélange or Aptian-Cenomanian shallow marine 
deposits, while in the southwestern (SW) and southern (S) parts they lie over the Paleozoic-Triassic rocks $[3,12,13]$ (Figure 1). These rocks predominate as clasts in conglomerates (Figure 1). In many cases, contacts between conglomerates and surrounding rocks are unclear, marked by a mylonitic shear zone (Figure 1). Pebbles, cobbles, and sporadically boulders are, in most cases elongate-oval, and mostly vary in size from 5 to $15 \mathrm{~cm}$ (largest axis), but can sometimes reach up to $75 \mathrm{~cm}$. Most of the pebbles are derived from low-metamorphic bedrock (slates, metagreywackes, chlorite-, sericite- and quartz-sericite schists) and their depositional environment was, up until now, described as coastal-alluvial, with alluvial and/or deltaic fans $[4,7,8,10]$.

The aim of this paper is to discuss the possible reservoir potential of studied conglomerates considering the following: (1) clast size and distribution, modal composition, porosity/permeability; (2) local depositional environment; and (3) regional position.

\section{Geological Setting}

Mount Medvednica, today $1035 \mathrm{~m}$ high, represents an uplifted structure derived from the Adria tectonic unit and situated where the Sava suture zone changes direction from NW to NE and continues into the Zagorje-Mid-Transdanubian Shear Zone [14-17], the transitional zone from the Alps to the Dinarides ([15-17], and references therein). It also represents the geological and geomorphological barrier between the Sava Depression and Konjščina Subdepression (part of the Mura Depression) deep basins, which were among the first Croatian regions subject to petroleum geology research.

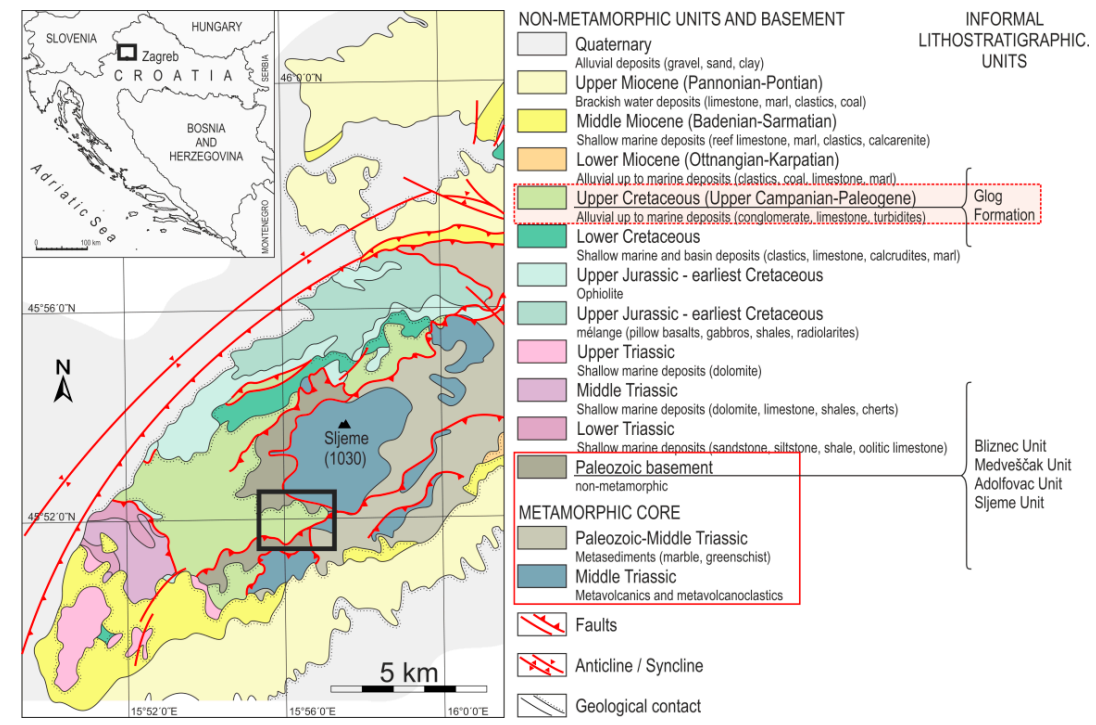

Figure 1. Geographic location and geological map of the study area (after [18], modified). Position of the studied sections is marked by a black rectangle on the map. Studied deposits belong to the Upper Cretaceous informal Glog Formation (sensu [11]) (highlighted in the Legend). Clasts are mostly composed of Paleozoic to Middle Triassic metasediments, rarely of metavolcanics, from the metamorphic core and Paleozoic non-metamorphic rocks (red rectangle on the Legend).

Medvednica metamorphic core is composed of metavolcanic and metasedimentary rocks [12,19], including phyllites, quartzites, metaradiolarites, marbles, metagreywackes and metaconglomerates [20,21]. Metavolcanics give a metamorphic age of 135-122 Ma based upon $\mathrm{Ar} / \mathrm{Ar}$ dating [22], while the peak metamorphism from metasediments was estimated at $100 \mathrm{Ma}$ [23-26]. A metamorphic overprint is probably related to the subsidence in a Gosau-type basin at $80 \mathrm{Ma}$ [22]. PT conditions point to $350-410{ }^{\circ} \mathrm{C}$ and $3-4$ kbar $[19,25,26]$. Low-grade (subgreenschist facies) metasediments crop out around the metamorphic core (Figure 1). They are mostly represented by pelagic black shales, turbidites and carbonates. Epidote-chlorite-actinolite-albite schists, named Sljeme Unit occur in the base. They are overlain by marbles interlayered with orthogreenschists 
and quartzites of the Adolfovac Unit, dark grey marbles and metaconglomerates of the Medveščak Unit and dark grey slates and phyllites of the Bliznec Unit (Figure 1) [24]. K-Ar dating of muscovite from metasediments points to a metamorphic event between 124-95 Ma [23,25] and temperature ranges from 100 to $240{ }^{\circ} \mathrm{C}$ [26]. The age of protoliths for metasediments and metavolcanics is estimated as Early Paleozoic to the Middle Triassic, based upon scarce pelagic fossils: graptolites and conodonts [27,28].

A chaotic mixture of blocks of ophiolites and sedimentary rocks embedded in fine-grained matrix crops out in the NW part of the Medvednica Mt., interpreted as a part of the Western Vardar ophiolitic mélange obducted during Mid-Late Jurassic-earliest Cretaceous times [15,29]. They are overlain with Aptian to Cenomanian shallow marine clastic and carbonate rocks ([17], and references therein).

Late Cretaceous clastic sedimentary rocks on southwestern slopes of the Medvednica Mt. transgressively lie over the Paleozoic to Triassic bedrocks in the area between Mikulić Potok Creek and Medvedgrad Castle [1,4,10,18] (Figures 1 and 2). They exhibit a transgressive pattern, evolving from debrites into turbidites, which are common along the Sava suture zone $[4,10,16,17,30,31]$. Their Santonian-Campanian age was interpreted on the basis of globotruncanid planktic foraminifera from overlying hemipelagic Scaglia Limestone [32]. Lužar-Oberiter et al. [31] describe clastic succession from the southern slopes of Mt. Medvednica as a Cretaceous synorogenetic Glog Formation (Figure 1) and presume the younger, Maastrichtian age. Similarity of Cretaceous clastic succession from Mt. Medvednica with contemporaneous synorogenic deposits of the alpine Gosau Group has been noticed by several authors $[12,17,22,25]$.

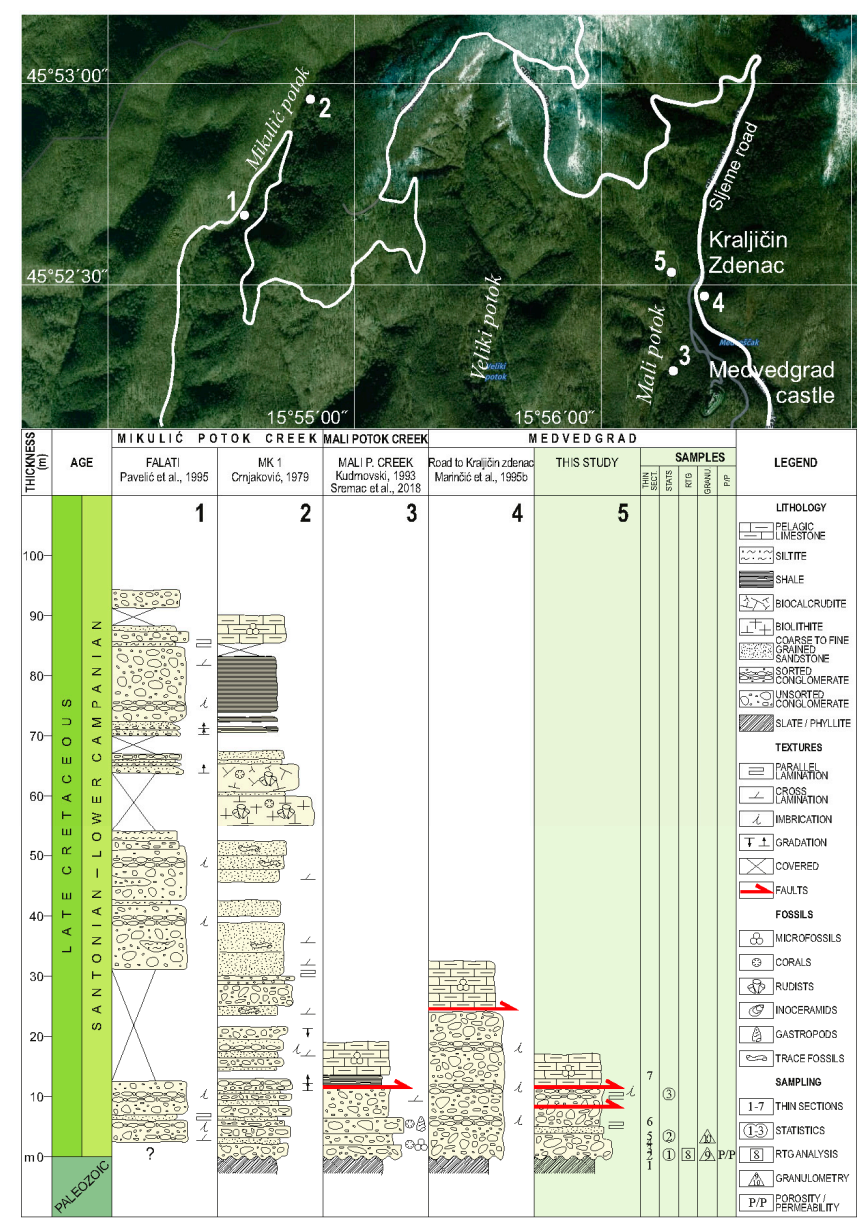

Figure 2. Location map of conglomerate outcrops in the south-western part of the Medvednica Mt. (1-5) and sedimentary logs of Upper Cretaceous clastic-carbonate successions, with position of sampling points (after $[4,7,8,10,30]$, this study). 
All these stratigraphic units are transgressively overlain by Miocene lacustrine/marine deposits of the Pannonian Basin ([3,17], and references therein; [21]) (Figure 1).

\section{Material and Methods}

The studied section, predominantly composed of conglomerates, was studied along the hiker's road from Medvedgrad Castle to Risnjak (Figure 2). Thickness and inclination of strata were measured in order to reconstruct sedimentary succession. Clasts of diverse lithologies were collected at seven sampling points: five at the first $20 \mathrm{~m}$ of the exposure, one in the middle of the exposure and one at its southernmost part, near the boundary with the younger, Scaglia Limestones (Figure 2).

After the recognition of clast types in the field, three points were chosen for clast count and measuring, situated at the beginning, in the middle and at the end of the studied section (Figure 2, circled Points 1-3). Altogether, 106 clasts were extracted by hammer from $1 \mathrm{~m} \times 1 \mathrm{~m}$ test areas (Figure 3), measured by a micrometer along all three axes (longest: $x$, intermediate: $y$, shortest: $z$ ) and crushed in order to recognize their lithology. Thirteen thin sections were prepared from clasts of different lithology at the Department of Geology, Faculty of Science in Zagreb.
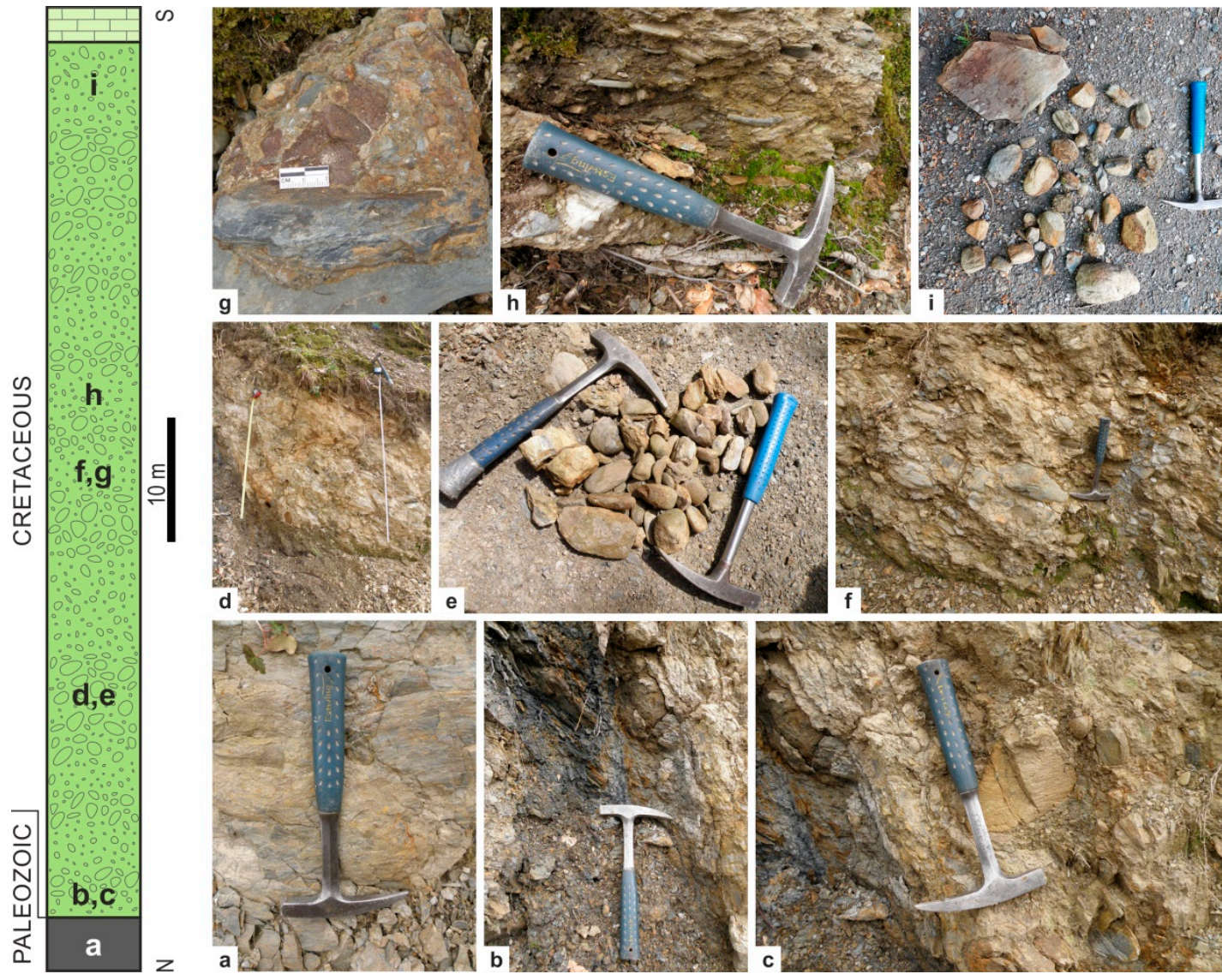

Figure 3. Field photographs from the studied section, with positions marked on a schematic column. (a) Weathered black slate in the base of the column; (b) boundary between the bedrock and conglomerate at Point 1; (c) enlarged detail of basal, poorly sorted conglomerate at Point 1; (d) area $1 \times 1 \mathrm{~m}$ chosen for clast count at Statistics Point 2; (e) measured clasts at Statistics Point 2; (f) conglomerates at Point 5; (g) enlarged detail from the Point 5; (h) imbricated conglomerates with angular quartz fragment at Point 6; (i) measured clasts at Statistics Point 3, Position of Points shown on Figure 2. Hammer length $33 \mathrm{~cm}$. 
Results of clast count and measuring are presented in modal charts and diagrams with particles classified into four categories: spheroids, discoids, rods or blades. Classification is based on the ratios between long (x), intermediate (y) and short (z) axes of the particles after Zingg [33].

Three conglomerate samples with different amount of matrix were taken for porosity analysis in the base of the section, after cleaning the weathered surface layers (Figure 2, samples marked by number 9 in a triangle). Two compact conglomerate samples were chosen for permeability analysis, one from the basal part of the section and one at $20 \mathrm{~m}$ southwards from the transgressive contact (Figure 2, samples marked by numbers 9 and 10 in triangles). Samples in the central and southern part of the section were not collected for this purpose because of tectonic deformations and weathering. Porosity/permeability analyses were prepared in the laboratory of INA d.d. in Zagreb. The porosity was determined on Corlab UltraPore 300 and standard Corelab helium porosimeter (Core Laboratories, Amsterdam, The Netherlands). The units measure the grain volume by allowing the helium or nitrogen to expand from the measuring cell of known volume and initial pressure. Grain volume is calculated according to the equation of state for real gases when the pressure drops and the gas enters the rock pores. Finally, porosity is calculated with the expression: Porosity $=($ Bulk Volume - Grain Volume $) /$ Bulk Volume. Bulk volume is determined using the standard caliper tool. Permeability was measured by a profile permeameter, by pressure-decay method, in several spots. Classical boring by 1" crown or extraction by methanol could not be applied, due to the weathering rate and condition of samples.

Outcrop, pebbles and macrofossils were photographed by a digital Olympus SP570UZ (Olympus Europe, Middle East and Africa, Zagreb, Croatia) and Samsung SM-G935F cameras (Samsung, Seoul, Korea). Microfossils were studied under Olympus-SZX10 stereo microscope (Olympus, Tokyo, Japan), photographed by Canon EOS 1100D camera and saved through the Quick PHOTO CAMERA 3.0 program. Minerals in thin sections were photographed under polarized light using the Zeiss Axiolab microscope and Canon 500D camera. All photomicrographs were taken at the Department of Geology, Faculty of Science, University of Zagreb.

\section{Results}

Our research focused on reconstruction of depositional succession, analyses of size, shape and composition of pebbles and matrix, permeability/porosity characteristics and age of the coarse-grained clastic succession in order to assess goal of reservoir characterization.

\subsection{Description of the Locality}

The studied section, oriented North-South, is exposed along the hikers' path leading northwards from the Medvedgrad Castle (coordinates: $45^{\circ} 52^{\prime} 31.84^{\prime \prime}$ N; $15^{\circ} 56^{\prime} 15.84^{\prime \prime}$ E) (Figure 2, locality 5). The section is ca. $90 \mathrm{~m}$ long. At the northernmost part of the section, transgressive contact with bedrocks (dark grey slates) is clearly visible (Figure $3 a, b$ ). At the southern part of the section, the argillaceous Scaglia Limestone occurs, but its contact with conglomerates is covered by soil and vegetation.

Studied deposits are generally massive, with erosional lower surface visible at the base of the section (Point 1, Figure 3b,c). Their orientation can be measured at the Point 5, where a fine-grained interlayer of breccio-conglomerates exhibits inclination towards the south-west at an angle of ca. $30^{\circ}$. Conglomerates are poorly sorted, clast-supported only at the base (3c) and matrix-supported along the rest of the open succession (Figure 3f,g). Imbricated conglomerates occur at the Point 6 (Figure 3h). Pebble- and cobble-sized grains are, in most cases, elongate (Figure 3g). Clasts in upper horizons are almost angular (Figure 3i); sporadic occurrence of large cobbles/boulders can be observed all along the section. Matrix is grey at freshly cut surfaces, changing color into yellowish-brown at weathered surfaces (Figure 3).

The Scaglia Limestones at the Southern edge of the studied section (Point 7) are well bedded, with bed thickness ranging between 5 and $10 \mathrm{~cm}$. Their color changes from grey to pinkish-red, which is typical for these deposits in the wider region (also known under the name Scaglia Rossa). 


\subsection{Composition of Pebbles}

Clasts of different lithology collected at seven points were selected for preparation of thin sections (Figure 2; Points 1-7).

Elongate dark grey slate/phyllite pebbles to cobbles derived from the bedrock of the transgressive sequence compose the largest cobbles and predominate all along the profile (Figure 3). These clasts break into small particles when hit by a hammer. Smaller, more rounded greenish-colored pebbles (epidote-chlorite schists, orthogreenschists), sandstone pebbles of different color (grey, greenish or red, sometimes yellowish from limonite), recrystallized limestones (marbles), conglomerates and microbreccias, quartzites and scarce large angular white quartz fragments (Figure 3g, clast under the hammer).

Slates and greywackes predominate at all three Statistic Points. Angular white quartz cobbles occur in central and upper parts of the section and amount of breccio-conglomerate pebbles increases in upper horizons of the studied section. At the same time, number of greenschists and chlorite schists decreases in younger horizons (Figure 4).
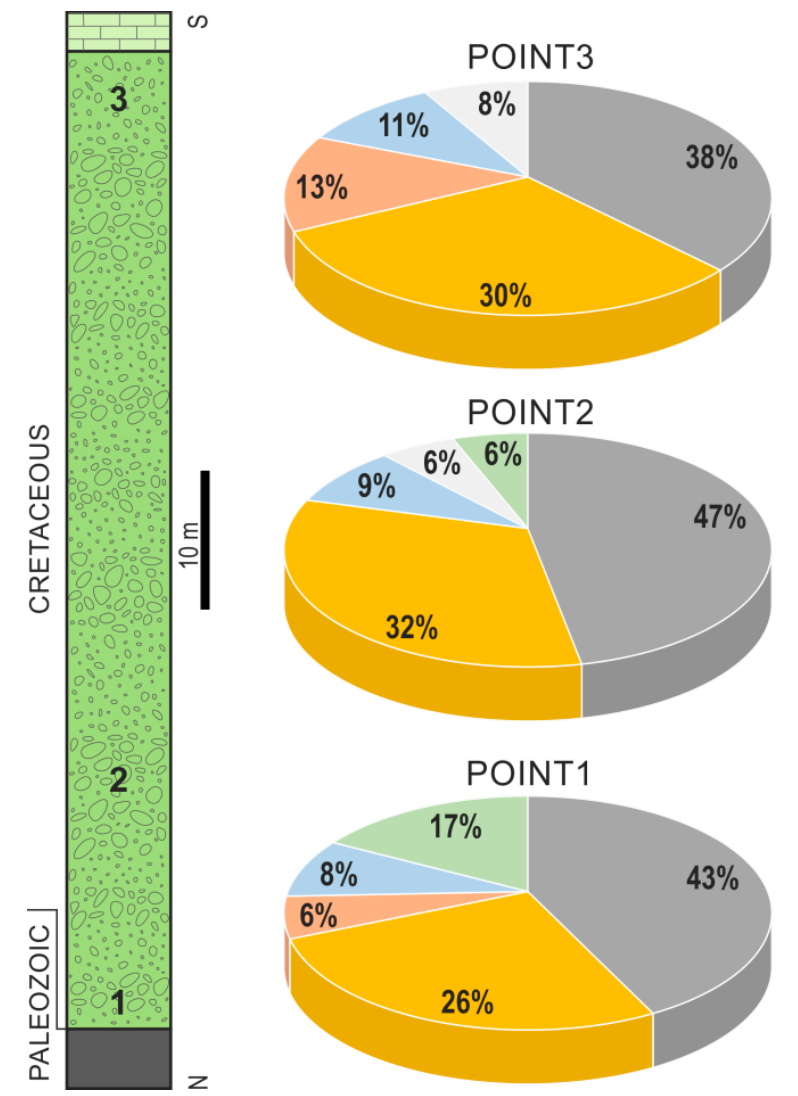

\begin{tabular}{|l|c|c|c|c|}
\hline & \multicolumn{4}{|c|}{ NUMBER OF PEBBLES } \\
\hline PEBBLE COMPOSITION & POINT1 & POINT2 & POINT3 & $\Sigma$ \\
\hline slate/phylite & 15 & 16 & 14 & 45 \\
\hline greywacke & 9 & 11 & 11 & 31 \\
\hline breccia/conglomerate & 2 & 0 & 5 & 7 \\
\hline low-metamorphic limestone & 3 & 3 & 4 & 10 \\
\hline quartz/quartzite & 0 & 2 & 3 & 5 \\
\hline green schist/chlorite schist & 6 & 2 & 0 & 8 \\
\hline$\Sigma$ & 35 & 34 & 37 & 106 \\
\hline
\end{tabular}

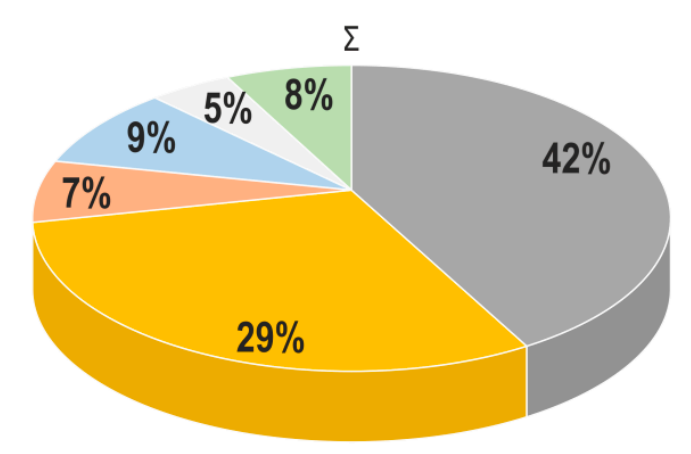

Figure 4. Modal composition of conglomerates based on 106 pebbles collected at Statistic Stops 1-3. Position of Statistics Points marked on a schematic column.

Greywackes are composed of lithoclasts, quartz grains and opaque minerals, accompanied with significant amounts of feldspars and epidote. Simple or complex (crenulated) cleavage occurs within almost all clasts, as well as the mylonite schistosity and rotation of grains (Figures 5 and 6). 


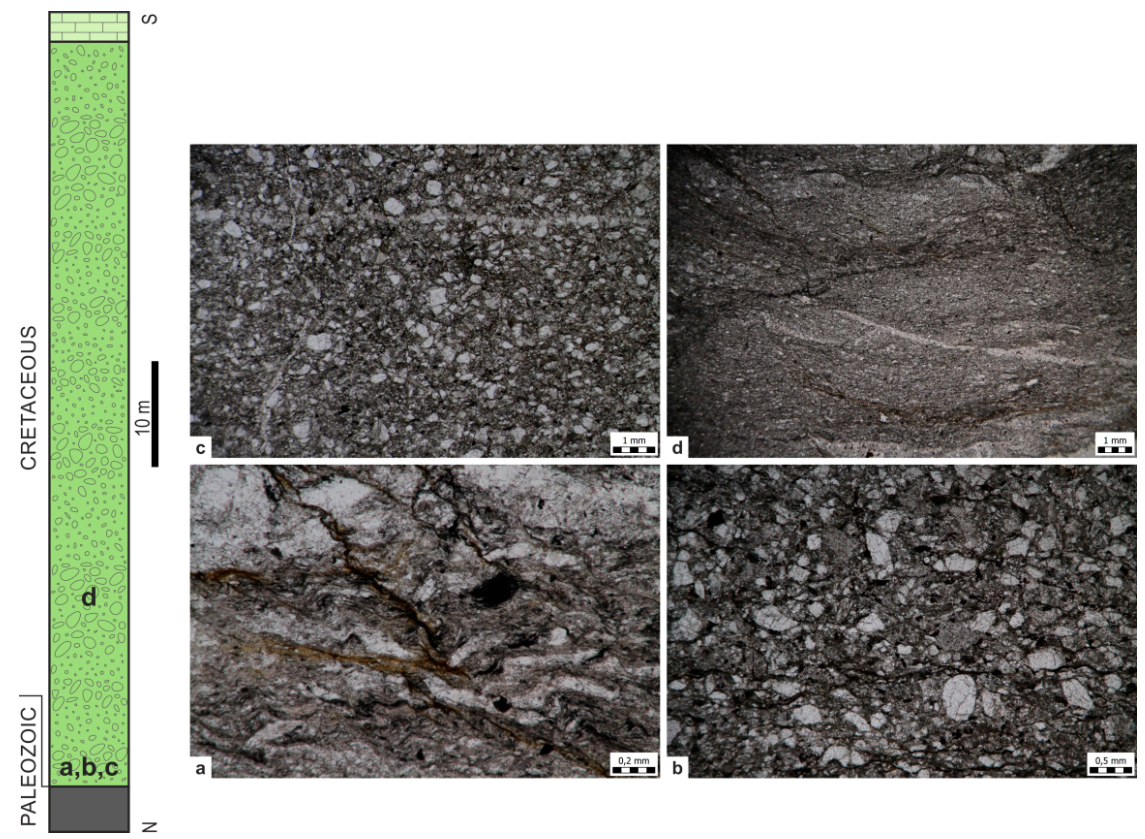

Figure 5. Photomicrographs of thin sections prepared from pebbles, in transmitted light: (a) fine-grained greywacke pebble in the base of the studied section, thin section $\mathrm{M}-0.1$; (b) black slate pebble with visible relic cross-bedding texture; thin section $\mathrm{M}-1.3$; (c) complex crenulate cleavage in a mylonitized greywacke, thin section $\mathrm{M}-1.3 ;(\mathrm{d})$ cleavage in greywacke pebble, with some rotated clasts, thin section M-6b. Position of Points marked on a schematic column.

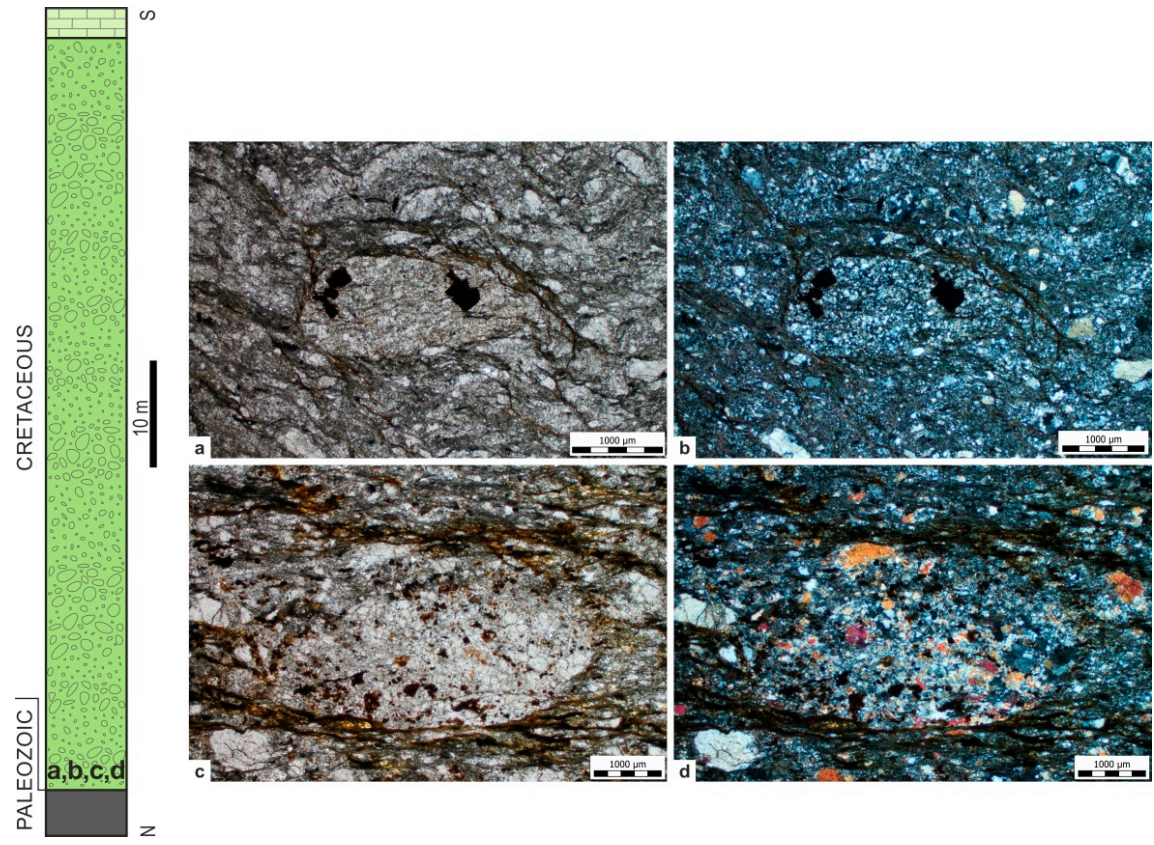

Figure 6. Pebble textures from Sampling Point 1 without (left) and with (right) polarizing analyzer filter: $(\mathbf{a}, \mathbf{b})$ crenulate cleavage and opaque grains in a mylonitized greywacke, thin section M-1.3.; (c,d) cleavage in a mylonitized greywacke, thin section M-1.8.

\subsection{Size Distribution and Shape of Pebbles}

Cobbles, even small boulders, are most common in the base of the transgressive succession, measuring up to $28 \mathrm{~cm}$ along the longest axis (Figure $3 \mathrm{c}, \mathrm{g}$ ). Finer-grained and better-sorted deposits occur in the central part of the profile, with most pebbles measuring between 3 and $10 \mathrm{~cm}$ along the longest axis (Figure 2e). Large, elongate, discoidal to rod-shaped clasts are usually composed of dark 
grey slate/phyllite or greywacke (Figure 2i). Finer-grained conglomerates exhibit better sorting and comprise a variety of clast forms (e.g., Statistics Point 2; Figure 7). Smaller clasts are often derived from chlorite schists, metaconglomerates and microbreccias, but small slate/phyllite and greywacke clasts are also common.
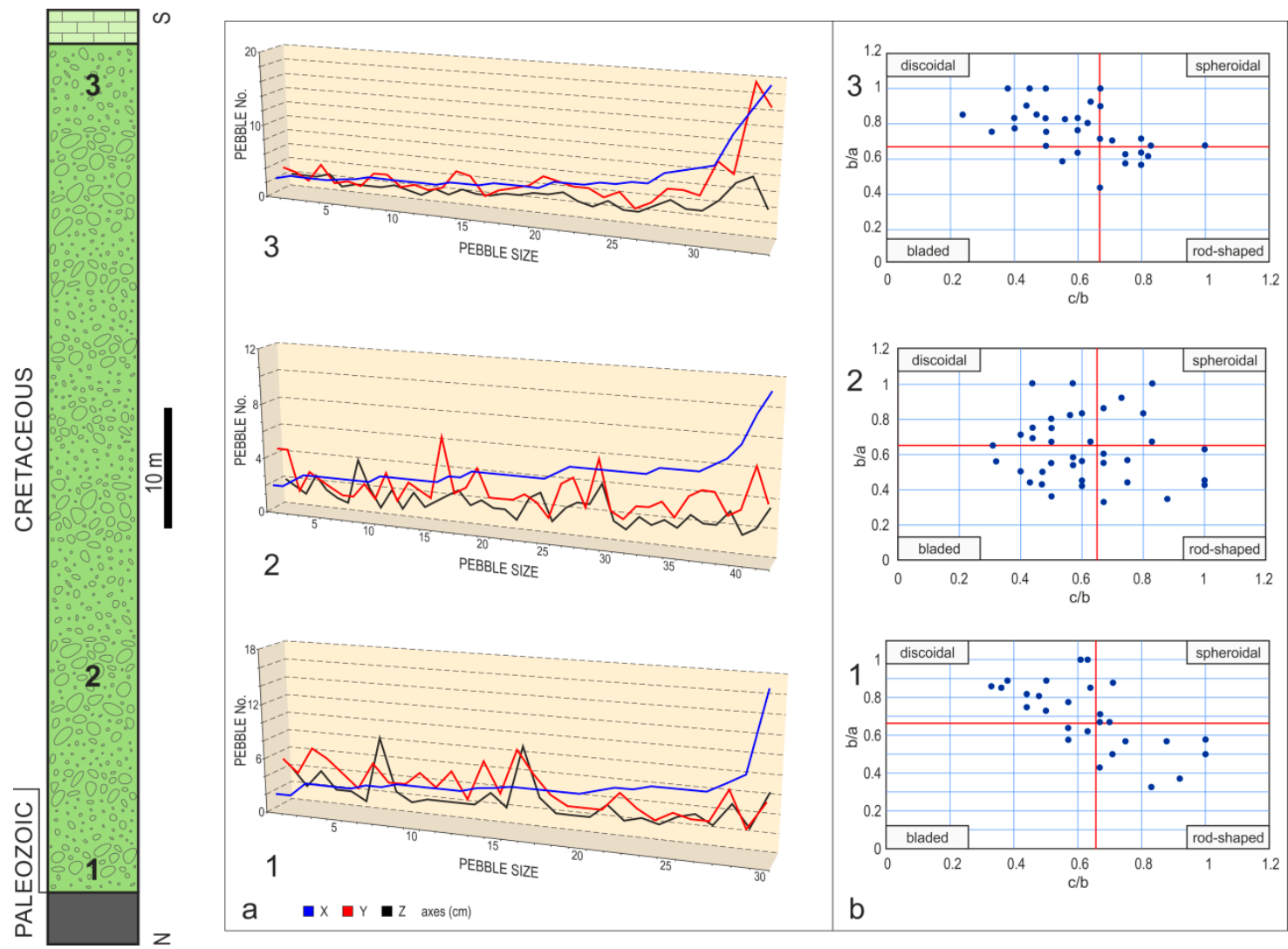

Figure 7. Distribution of clast size across $x, y$ and $z$ axes at Statistics Points 1, 2 and 3. Shape of clasts presented according to Zingg [33]. Position of sampling points shown on a schematic column.

Similar variations of clast sizes occur within the Cretaceous conglomerates in the wider area. At the locality Mali Potok Creek, clast sizes vary from 0.4 to $75 \mathrm{~cm} \mathrm{[10],} \mathrm{while} \mathrm{at} \mathrm{the} \mathrm{Falati} \mathrm{locality} \mathrm{[8]}$ they reach $50 \mathrm{~cm}$. Clasts in Mikulić Potok Creek conglomerates are smaller, varying 0.4-16 cm [4,7] (position of localities at Figure 2).

In most cases conglomerate textures are chaotic, but imbricated packages appear at the upper stream of Mikulić Potok Creek [4], at several horizons at the Falati locality [8] and along the road Medvedgrad Castle-Kraljičin Zdenac Well [7] (Figure 2). Imbrication is visible in the central part of the section described in this study (Figure $3 \mathrm{~h}$ ).

\subsection{Matrix}

Conglomerates at the base of the section are clast-supported, with the amount of matrix being less than $15 \%$. The amount of matrix in the central and upper parts of the column reaches up to $50 \%$ of the rock volume. Matrix is of greywacke type with dominance of quartz grains and lithoclasts composed of the rocks present as clasts in conglomerates. Their composition remains unchanged along the studied section, but they are coarser-grained at the base of the section (Figure 8). Epidote mineral grains are also common, composing up to $7 \%$ of the matrix. 

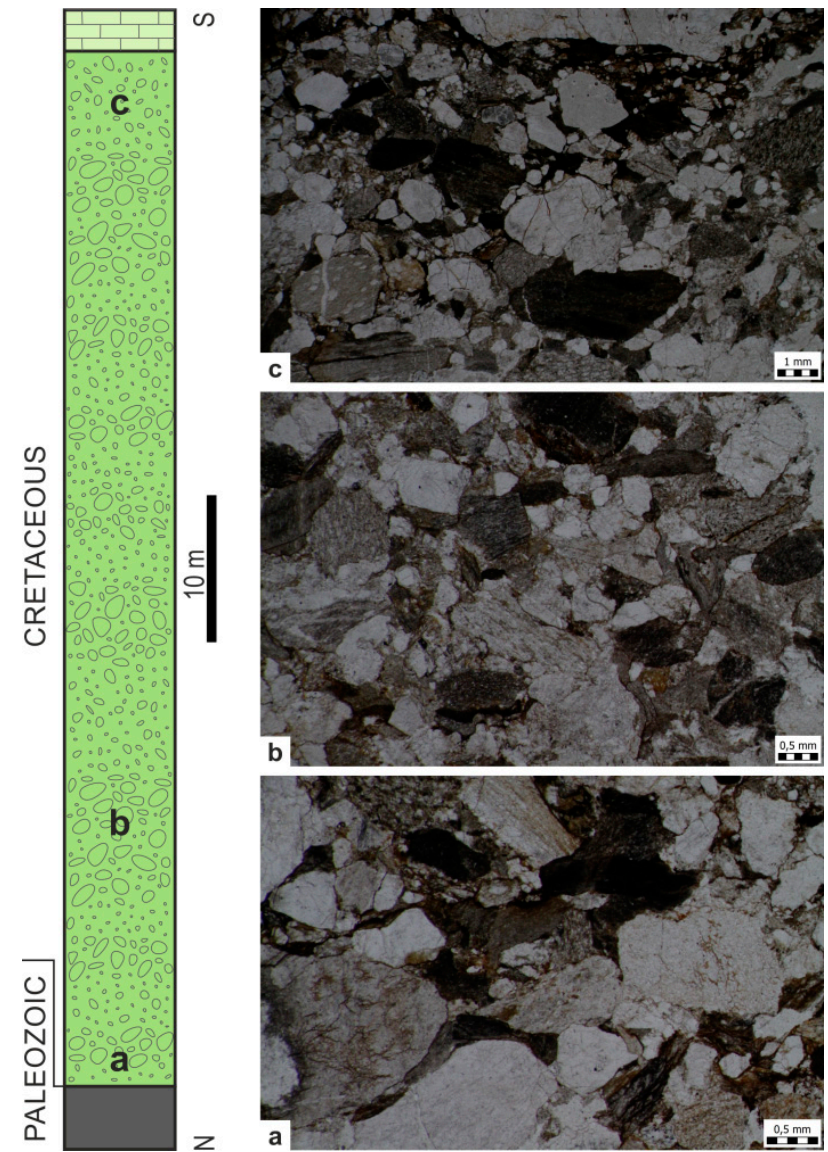

Figure 8. Photomicrographs of conglomerate matrix from Statistic Points 1 (a), 2 (b) and 3 (c) in transmitted light. Position of sampling points shown on a schematic column.

Other studies report similar amounts of matrix in Mikulić Potok Creek (9.8\%-45.5\%) [4] and in Mali Potok Creek (10\%-15\%) [10]. Conglomerates between Mali and Veliki Potok Creeks [10] contain fossils in matrix, such as red algae, benthic foraminifera, mollusks and echinoderms.

\subsection{Permeablity and Porosity}

Porosity and permeability are important technical characteristics of reservoir rocks, influencing the hydrocarbon reserves and financial profitability of exploitation. During the field work, three conglomerate samples with slate clasts (Figure 9) were chosen for porosity / permeability analyses, after cleaning the weathered surface layer (samples I., II. and III.). Samples were taken from the basal part of the section, with no visible fractures. Primary porosity occurs in the matrix, while no porosity was observed within the clasts. No secondary porosity is visible. The following values were calculated: Sample I.-- porosity of $10.89 \%$; sample II. $-8.85 \%$; and sample III.-4.98\%. Sparse values are usual in such type of rocks. Nevertheless, these rocks are estimated as potential reservoir rocks, because two values are higher than minimal $8 \%$ porosity necessary for formation of hydrocarbon reserves. 


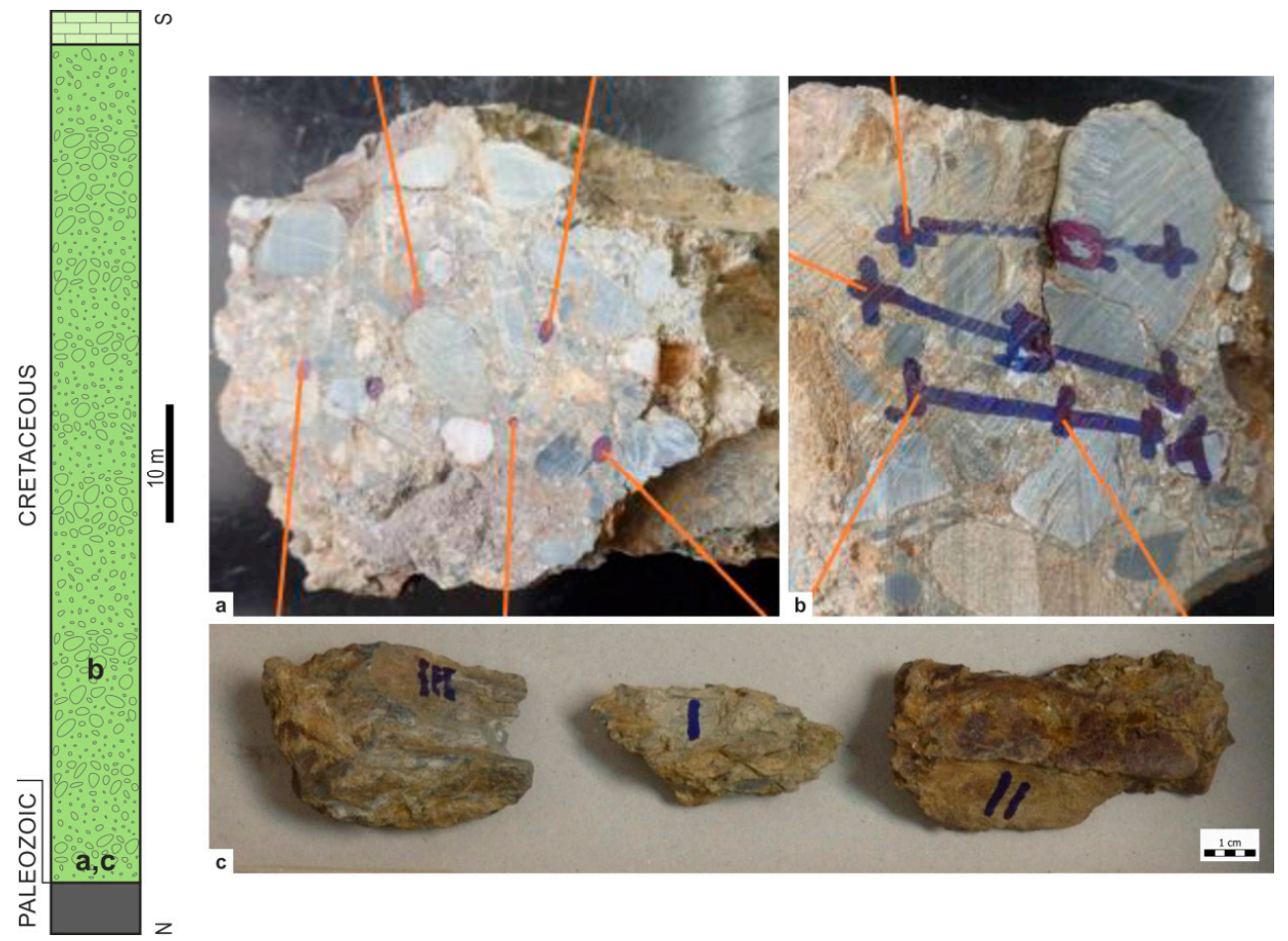

Figure 9. Samples taken for permeability $(\mathbf{a}, \mathbf{b})$ and porosity (c) analyses, at Statistic Points 1 (c) and $2(\mathbf{b}, \mathbf{c})$. Measuring positions within the matrix marked by numbers on photos. Position of sampling points in the matrix marked on a schematic column.

Samples IV. and V. were chosen for permeability analyses (Figure 9). They were first dried at $80^{\circ} \mathrm{C}$ during $24 \mathrm{~h}$ and cut in order to obtain plain surface, ca $10 \mathrm{~cm}$ long. Obtained values sometimes reflect the secondary, fracture permeability, rather than primary matrix permeability, but samples were taken from the lower part of the section, with no visible tectonic faults and fractures. Permeability measured in sample IV. is rather high (measuring positions 1-5, Table 1) and points to the quality of the reservoir rock. The permeability of sample V., measured at 4 positions, is very low (Table 1 ).

Table 1. Permeability values measured at five positions within the samples.

\begin{tabular}{cccc}
\hline Sample & Sample Section & Measured Permeability $(\mathbf{m D})$ & Corrected Permeability $(\mathbf{m D})$ \\
\hline IV & 1 & 9.84 & 8.21 \\
IV & 2 & 11.7 & 9.88 \\
IV & 3 & 47.8 & 43.3 \\
IV & 4 & 39.5 & 35.5 \\
IV & 5 & 52.1 & 47.4 \\
V & 1 & 3.25 & 2.51 \\
V & 2 & 1.57 & 1.13 \\
V & 3 & 2.58 & 1.96 \\
V & 4 & 2.38 & 1.79 \\
\hline
\end{tabular}

\subsection{Paleontological Research}

Bioclasts (red algae, benthic foraminifera, corals and gastropods) occur in the conglomerate matrix at nearby outcrop Mali Potok [10]. Trace fossils were recorded from a sandstone intercalation and roof-rock at Mikulić Potok locality [4]. Inoceramid bivalves (Inoceramus sp.), corals and rudists (Vaccinites sulcatus Defrance, V. praesulcatus Douvillé, V. gosaviensis Douvillé and V. oppeli oppeli Kuhn) occur at the same locality [6]. Nannoplankton analyses were done only from one locality, presenting the following taxa from flysch-type deposits overlying the conglomerates: Watznaueria barnesae (Black), 
Retecapsa angustiforata (Black), Micula staurophora (Gardet) Stradner and Broinsonia parca constrica (Hattner et al.) (Table 2) (from [6]; taxon names revised according to [34-36].

Uppermost, pelagic deposits at the studied outcrop are the Scaglia Limestones with pelagic foraminifera (Figure 10; Table 2): Globotruncana linneana (d'Orbigny), G. bulloides Vogler, G. cf. ventricosa, G. orientalis El Naggar, Globigerinoides cf. bolli Pessagno and Heterohelix punctulata (Cushman).

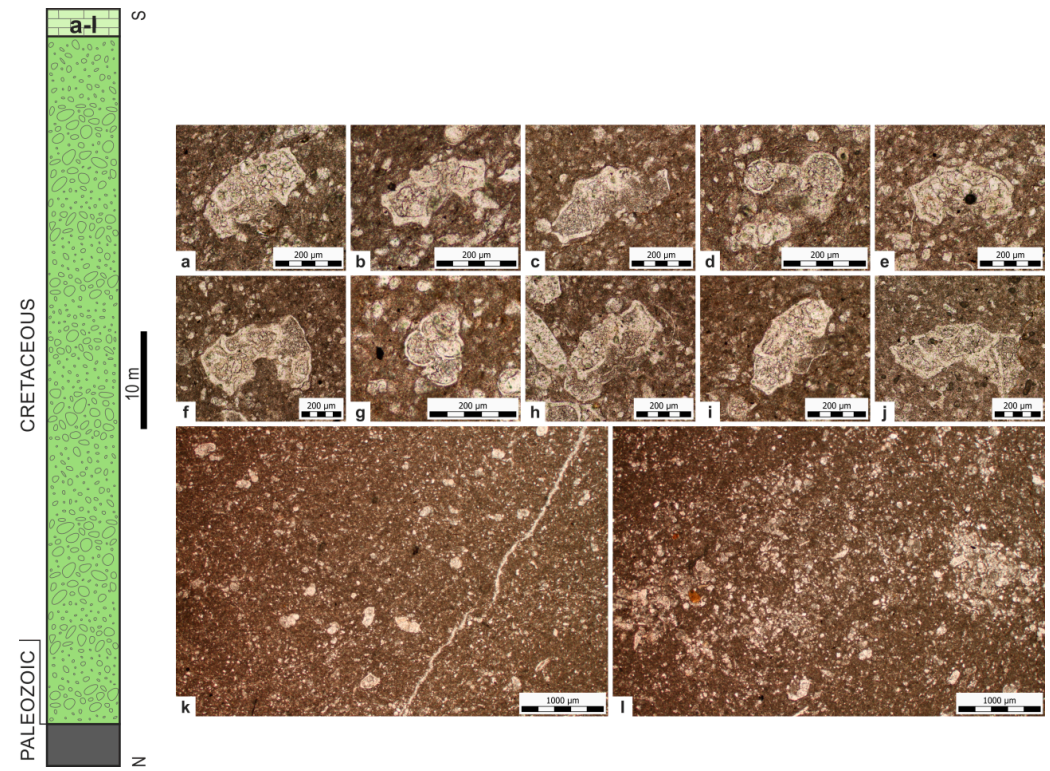

Figure 10. Photomicrographs in transmitted light of planktic foraminifera and pelagic facies from the Scaglia Limestones at the top of the studied section. (a,i) Globotruncana linneana (d'Orbigny): (b) Globotruncana bulloides Vogler: (c) Marginotruncana pseudolinneana Pessagno; (d) Globigerinoides cf. bolli Pessagno; (e,f) Globotruncana cf. ventricosa White; (g) Heterohelix punctulata (Cushman); (h) Globotruncana cf. linneana (d'Orbigny); (j) Globotruncana orientalis El Naggar. Panoramic view of two types of pelagic deposits: nonlaminated (k) and slightly laminated (1). Position of Sampling Stop 7 marked on the schematic column.

\section{Discussion}

Data obtained through this study, combined with published descriptions of contemporary outcrops in the wider area, enabled the reconstruction of depositional processes and regional basin characteristics.

\subsection{Clast Provenance and Their Distribution}

All collected pebbles and cobbles found at the studied section were derived from rocks today surrounding the research profile. These rocks represent the Paleozoic basement and metamorphic core of the Medvednica Mt. ([3,13], and references therein; [18]) (Figure 1). Predominant large, elongate dark grey slate clasts (Figure 4) belong to the youngest low-metamorphic (Lower Paleozoic-Triassic) horizon, informal Bliznec Unit (sensu [23,24]). When unroofed at the outcrop, they start decomposing in a very short time, along the cleavaged surfaces, and it is obvious that they were not transported long distances. Sandstones and, more common, greywackes are the second most abundant sources of pebbles. They are less elongated, better rounded and usually somewhat smaller than slate clasts. Some pebbles are composed of dark grey marbles and metaconglomerates derived from the underlying Medveščak Unit and orthogreenschists and vein quartz of the Adolfovac Unit. Epidote-chlorite-actinolite-albite schists of the oldest, Sljeme Unit (sensu [22,23]) occur only sporadically (Figure 4). Marbles and schists from the metamorphic core are scarce. Less rounded clasts in younger section horizons (Statistic Point 3, Figure 3 i) suggest a very short transport and reduced sediment reworking along the beach. 
Poorly sorted conglomerates, without well-developed bedding planes, containing some very large clasts, were probably transported by debris flows, similar as such deposits at neighboring localities $[4,7,8,10]$. Only sporadically smaller clast size and their more even distribution can be observed in the central part of the section, pointing to the longer reworking period along the shallow shelves. Imbrication is visible in one horizon in the central part of the section, but it is rather common at Falati locality, where five such horizons were recognized (Figure 2). Such transport of clasts in a suspension, without significant tumbling and rolling, can be observed in modern coastal/alluvial environments [37]. It is more probable that debris deposited at the studied section was carried as a bedload. Bimodal clast size distribution visible along the section (Figure 7) suggests the occasional new input of coarse-grained debris into the basin.

At the locality Mali Potok Creek, only several hundred meters away (Figures 2 and 11), pebbles and matrix were dominantly derived from low-metamorphic quartz-chlorite, quartz-epidote and epidote-chlorite schists of the oldest, Sljeme Unit and are commonly rounded [10,30], pointing to the longer reworking period.
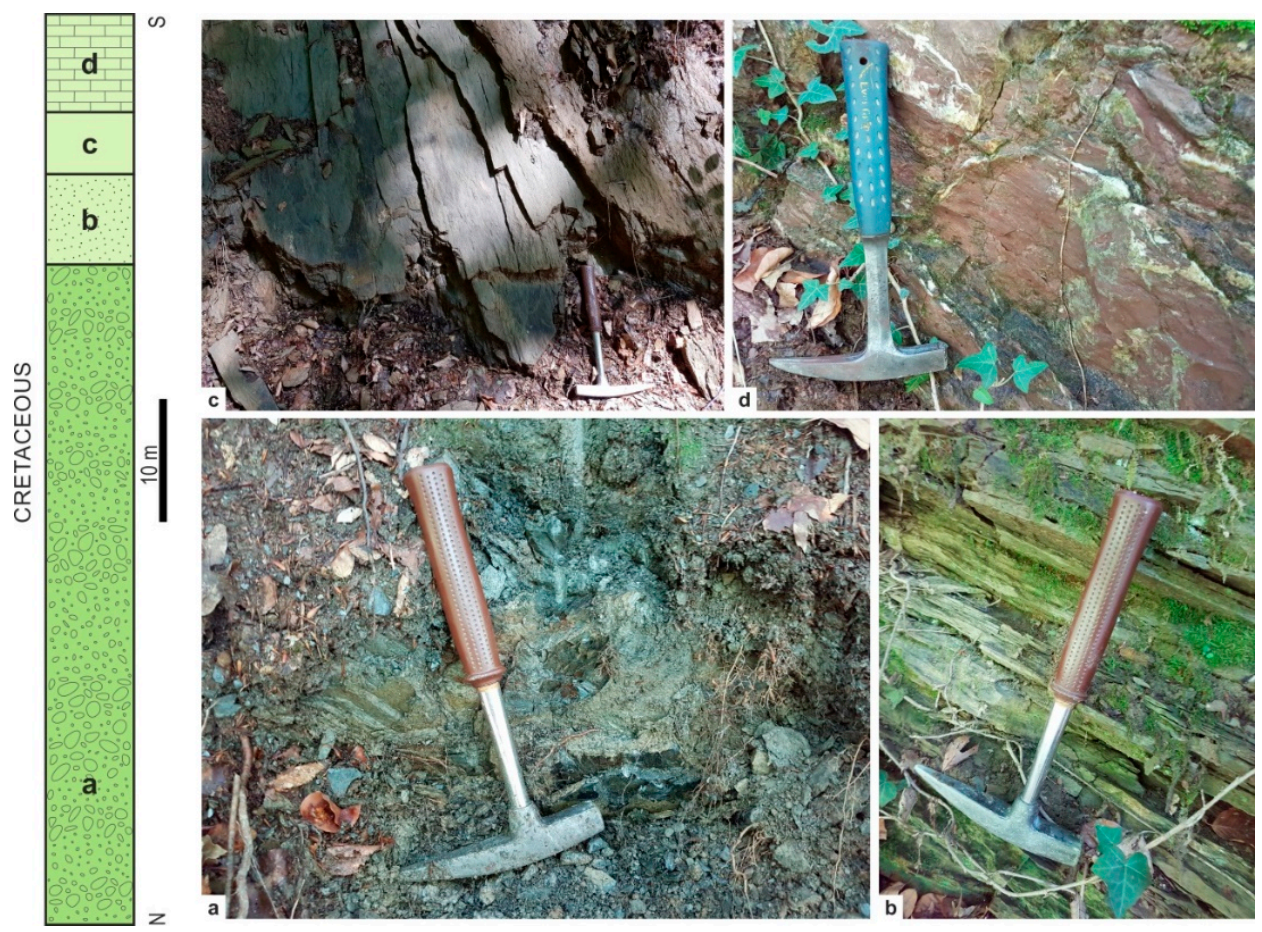

Figure 11. Field photographs of: (a) conglomerates; (b) sandstones; (c) shales and (d) the Scaglia Limestones between Mali Potok and Veliki Potok Creeks, studied by [10,30], revisited during this study. Position in the stratigraphic succession described by [10] marked on a schematic column.

Mylonitization, commonly visible in clasts, points to the vicinity of a shear-zone, probably formed during the Cretaceous nappe-stacking event $[12,13,38]$. Complex cleavage visible in some slate and greywacke pebbles indicates multiphase tectonic events (during the Hercynian and early Alpine orogeny).

Sandstones overlying conglomerates in the studied area contain the dominant zircon-tourmaline-rutile mineral association, while epidote and garnet occur in small quantities [26,32]. We may conclude that a major change happened after the deposition of conglomerates at the studied localities, indicating the change of provenance from continental to continental-ophiolitic. 
Table 2. Stratigraphic span of planktic foraminifera found in the Scaglia Limestones from the southwestern and southern part of the Medvednica Mt. ([32,39], this study) and calcareous nannoplankton found at Mikulić Potok Creek [6]. Fossil names from previous studies revised according to [34-36]. Presence of fossils marked by $x$ and their stratigraphic span by grey stripes. Fossils determined during this study highlighted by pink background.

\begin{tabular}{|c|c|c|c|c|c|c|}
\hline Foraminifera & {$[32,39]$} & This Study & $>$ Coniacian & Santonian & Campanian & Maastricht. < \\
\hline Globotruncana lapparenti Brotzen & $\mathrm{x}$ & $x$ & & & & \\
\hline Globotruncana tricarinata (Quereau) & $\mathrm{x}$ & & & & & \\
\hline Radotruncana calcarata (Cushman) & $\mathrm{x}$ & & & & & \\
\hline Globotruncana arca (Cushman) & $\mathrm{x}$ & & & & & \\
\hline Globotruncanita conica (White) & $\mathrm{x}$ & & & & & \\
\hline Contusotruncana fornicata (Plummer) & $\mathrm{x}$ & & & & & \\
\hline Globotruncana linneiana (d'Orbigny) & & $\mathrm{x}$ & & & & \\
\hline Globotruncana bulloides (Vogler) & & $\mathrm{x}$ & & & & \\
\hline Globotruncana orientalis El Naggar & & $\mathrm{x}$ & & & & \\
\hline Globotruncana cf. ventricosa White & & $\mathrm{x}$ & & & & \\
\hline Marginotruncana pseudolinneana Pessagno & & $x$ & & & & \\
\hline Globigerinoides cf. bolli Pessagno & & $\mathrm{x}$ & & & & \\
\hline Heterohelix punctulata (Cushman) & & $\mathrm{x}$ & & & & \\
\hline Calcareous Nannoplankton & [6] & & & & & \\
\hline Watznaueria barnesae (Black) & $\mathrm{x}$ & & & & & \\
\hline Retecapsa angustiforata (Black) & $\mathrm{x}$ & & & & & \\
\hline Micula staurophora (Gardet) Stradner & $\mathrm{x}$ & & & & & \\
\hline Broinsonia parca constrica (Hattner et al.) & $\mathrm{x}$ & & & & & \\
\hline
\end{tabular}

\subsection{Depositional Model}

Comparing conglomerate successions in the wider area (Figure 2), the study area shows similarities in overall thickness, chaotic composition, large clasts and poor sorting with nearby profiles described from Mali Potok Creek [10] and road to Kraljičin Zdenac [7]. At least two debrite episodes can be recognized at the studied section and in Mali Potok Creek. Along the road to Kraljičin Zdenac, four debrite packages occur. Falati locality [8] exhibits similar rocks, but in a significantly thicker sequence, with several imbricated horizons, five or more debrite episodes and some visible channel structures. Downstream of the Mikulić Potok Creek, the most complete Late Cretaceous succession in this area crops out [7]. Conglomerates at this locality are composed mostly of greywacke pebbles. In upper horizons they are gradually replaced by sandstone with small inoceramids, and sporadic rudist-coral patch reefs. Conglomerate outcrop described by [4] differs from other sites in developed bedding planes, sandstone intercalations, sporadically visible grading and thick sandstone horizon deposited above the conglomerates (Figure 12).

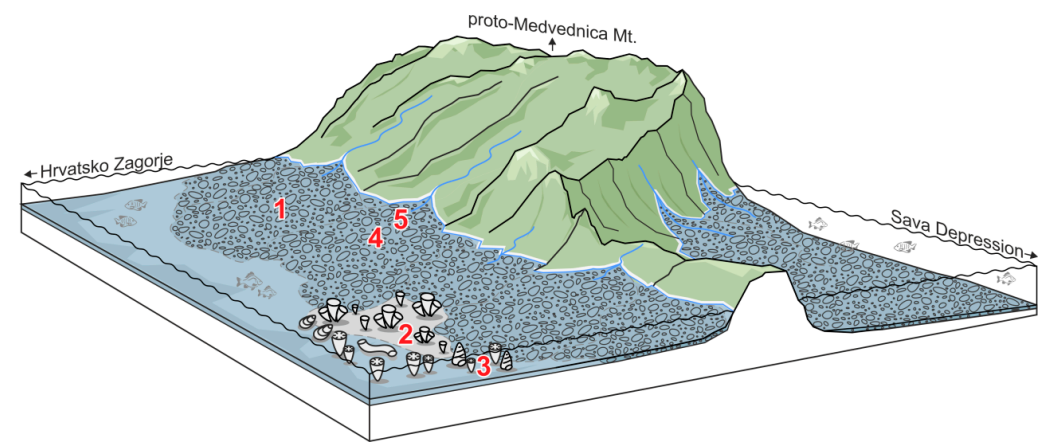

Figure 12. Depositional model of Late Cretaceous clastic deposits in the studied area with presumed positions of localities shown on Figure 2: (1) Falati; (2) Mikulić Potok Creek; (3) Mali Potok Creek; (4) Road to Kraljičin Zdenac; (5) Studied section.

Locality 2, with debrite package in the base, overlain by sandstones and rudist patch-reefs described by [4], was probably positioned in slightly deeper water, and away from the feeding flows. Locality 3 was situated in a rather favorable environment which enabled the settlement of some benthic biota (e.g., red algae, large benthic foraminifera) (Figure 12). 
Considering all available data, the whole clastic-carbonate succession can be related to the unroofing and extension in a Gosau-type basin. Poorly sorted conglomerate packages with massive clasts were derived from the local bedrock. Clasts were transported over short distances, probably by torrents or short-lived river-flows (Localities 1, 4 and 5). There is little possibility of alluvial/deltaic transport, as suggested by previous authors $[4,7,8,10]$, as proto-Medvednica Mt. at the Cretaceous time was an island too small to develop an alluvial system, and pebbles and matrix are of the strictly local character.

\subsection{Age of Transgression}

Fossils have not been found in conglomerate horizon at the studied section. Therefore, the only possibility to date the age of the succession was according to the foraminifera from the overlying Scaglia Limestone, exposed in the southern part of the section (Figure 2).

Planktic foraminifera were previously determined from several localities in the western part of the Medvednica Mt., e.g., along the creeks Kraljevečki Potok, Veliki Potok, Mali Potok, Vrabeščak [39]. Later on, findings of globotruncanids were discussed from other localities at the Medvednica Mt. [2,32,40]. Neděla-Devidé [39] determined the biostratigraphic ranges of planktic foraminifera from the southern and southwestern Medvednica Mt. (Table 2) as middle to early upper Campanian. Hu et al. [41] date the Cretaceous oceanic red beds (CORBs), corresponding to the Scaglia Limestones, and conclude that most of the Tethyan deposits are Turonian to Maastrichtian age (CC11-26 Calcareous Nannofossil Zones). Additional biostratigraphic data can be derived from nannotaxa, particularly Broinsonia parca constrica, which has the most indicative time-span, ranging from the Campanian to the Maastrichtian (Table 2).

Considering the global sea level events and revised biozones ([40-43], and references therein), R. calcarata determined by [39] from neighboring localities corresponds to the middle Campanian CC22 Nannozone. Species Marginotruncana pseudolinneana found during this study thrives from the Coniacian into the Santonian, possibly the lowermost Campanian. Therefore, pelagic roof-rocks in the area of the Medvednica Mt. could be dated as the lowermost (at the research locality) to the middle Campanian (at some neighboring localities). Presumably sinking and uplifting of blocks building the Medvednica Mt. was diachronous, and the Scaglia Limestones from different localities could be of different age.

According to these data the probable age of the underlying clastic succession from the studied section is Upper Santonian, near the Santonian/Campanian boundary (83.6 Ma, [44]). A short-term (3rd-order) sea-level curve [45] points to the low-stand episode around $84 \mathrm{Ma}$, which could correspond to the age of the studied conglomerates.

\subsection{Reservoir Potential of Cretaceous Conglomerates}

The Croatian part of the Pannonian region, according to the international standards, is considered a well-researched region, having more than one exploratory well across $1000 \mathrm{~km}^{2}$. Nevertheless, the depth of drilling is not sufficient [46-48]. In an area of ca. 30,000 $\mathrm{km}^{2}$, a little less than 4000 boreholes were drilled, with more than 3000 situated within the oil fields, and fewer than 900 positioned between them. Only $16 \%$ of all boreholes reached the so-called pre-Neogene rocks $([49,50]$, and references therein).

This is rather strange, because some of the richest hydrocarbon reservoirs in Croatia are situated in Paleozoic/Mesozoic rocks of the Pannonian region, e.g., gas fields Molve, Kalinovac and Stari Gradac. Molve Field, situated in the Drava Depression ca. $100 \mathrm{~km}$ eastward of the studied section, is the largest Croatian gas-condensate reservoir. Reservoir depths are greater than $3000 \mathrm{~m}$ and temperatures range between $182^{\circ} \mathrm{C}$ and $190{ }^{\circ} \mathrm{C}$. Pre-Neogene rocks in this area include secondarily porous, weathered, fractured and tectonized dolomites, breccio-onglomerates, limestones, sandstones, granites, gneisses and schists. Different pre-Neogene horizons can be recognized from regional seismic charts, but their age is just presumed [49]. e.g., some breccio-conglomerates mentioned 
in this study (as Lithofacies II), classified as the Triassic, might be of the Upper Cretaceous age. Unfortunately, porosity and permeability data from these older horizons are not available.

Thickness of Mesozoic complex north from the Medvednica Mt., as a part of the Zagorje-Balaton Zone, is estimated to $2000 \mathrm{~m}$ [49]. So-called "Mesozoic Depression Zone", as named by [51], is filled with limestones, dolomites and clastites. The uppermost part of the Mesozoic succession is composed of conglomerates and basal breccio-conglomerates [51] pointing to the possible connection with the deposits of the research area. Due to the intensive neotectonic activity Mesozoic rocks were subsided to $2800 \mathrm{~m}$ under the surface [52].

Oil and gas reserves in Cretaceous rocks are widespread in other tectonic units of Europe, in Czech Republic, Slovakia, Austria, Hungary, Serbia, Romania and Bulgaria. Some Austrian reservoir rocks (e.g., in famous Austrian oil fields Voitsdorf, Teufelsgraben-Stadlkirchen, Than and Trattnach), discovered between 1930 and 1978, are composed of Cretaceous sandstones, limestones and dolomites [53]. Late Cretaceous conglomerates as reservoir rocks were detected in the wider Pannonian region (Vojvodina, Serbia) in the late sixties of the 20th century [54]. Porosity values for these rocks reached $25 \%$. There are no data on permeability of these deposits. Research of the Mesozoic basement, including the Late Cretaceous deposits, was performed by drilling 190 boreholes in the southern Bačka and Banat provinces, ca. $300 \mathrm{~km}$ eastwards from the Medvedgrad outcrop [52]. In this region, Triassic, Jurassic and Cretaceous rocks were found. Late Cretaceous deposits are predominantly composed of siltites, but they also comprise significantly thick breccias or conglomeratic horizons, e.g., in the borehole Jaša Tomić-1 between 2212 and $1868.6 \mathrm{~m}$ and in the borehole Orlovat- 1 in interval between 1045 and $683 \mathrm{~m}$, pointing to the 350-m-thick conglomerate beds. Late Cretaceous rocks underlying the Miocene deposits in the borehole Bački Petrovac-1, ca. $50 \mathrm{~km}$ eastwards from Vinkovci, in the interval between 1382 and $1480 \mathrm{~m}$ (98 m thickness), are represented with conglomeratic sandstones [51], all together pointing to the wide distribution of coarse-grained clastics in this region.

Data from this study point to the possible reservoir potential of the Cretaceous conglomerates from the Medvednica Mt., considering their porosity/permeability features and overlying potential sealing rocks: shales and the Scaglia Limestones. Silurian to Middle Triassic pelagic deposits, black shales with graptolites and conodonts could be the source rocks for Upper Cretaceous reservoirs. Further subsurface explorations should be focused on the surrounding subsided areas. They should be explored from the aspect of possible stratigraphic or structural/stratigraphic traps.

Considering the Pannonian basin source rocks, the main oil/gas reserves are derived from the Middle to Late Miocene deposits in Sava and Drava Depressions [55-57] and Early Miocene in Mura Depression [58]. Researchers since 1991 have considered the existence of pre-Neogene source rocks. Some of the new research data from Cretaceous deposits in the study area point to the temperatures and pressures sufficient for formation of hydrocarbons, e.g., $[19,25,26]$. Therefore, additional attention should be paid to the Upper Cretaceous fine-grained clastic rocks, e.g., black shales described from the locality Mali Potok [10], from the aspect of possible source rocks.

\section{Conclusions}

Late Cretaceous conglomerates from the southwestern part of the Medvednica Mt. are polymictic, grain- to matrix-supported, and poorly sorted, with pebbles originating from the local Paleozoic to Triassic bedrocks.

Clastic material was transported from the proto-Medvednica Island by short-term torrents, rather than by rivers (as previously presumed) and deposited along the shelves. During the subsidence phase in a Gosau-type basin, conglomerates were replaced by flysch deposits and finally overlain by pelagic limestones.

Upper Santonian age of the clastic succession is presumed by superposition, based on calcareous nannoplankton and planktic foraminifera found in the overlying pelagic sediments. Transgression corresponds to the sea-level rise recorded at ca. 84 Ma. 
Cretaceous rocks were traditionally considered bedrocks during petroleum research in Northern Croatia. Their features, as described in this study (porosity, permeability and sealing roof-rocks), classify them as possible reservoir rocks, particularly in the depressions surrounding Mt. Medvednica. According to the $\mathrm{P} / \mathrm{T}$ conditions, black shales occurring in the topmost horizons of the clastic succession could even be considered as possible source rocks.

This study contributes to better understanding of structure, composition and development of the Croatian part of the Pannonian Basin, opening some new directions for the future hydrocarbon explorations.

Author Contributions: Conceptualization, J.S. and J.V.; Formal analysis, M.B. and T.T.-C.; Investigation, J.S., J.V., M.B., I.V. and D.K.; Methodology, T.T.-C.; Software, D.K.; Supervision, J.S. and I.V.; Validation, I.V.; Visualization, J.S.; Writing—original draft, J.S.; Writing—review \& editing, J.S., J.V. and M.B.

Acknowledgments: The authors are grateful to project leaders Alan Moro, associate professor at the Faculty of Science (University of Zagreb support "Sedimentology and paleontology of sedimentary successions from Outer and Inner Dinarides"), and Tomislav Malvić, full professor at the Faculty of Mining, Geology and Petroleum Engineering (University of Zagreb support: "Mathematical Research in Geology III.") for their professional support and providing access to the laboratory equipment. We also express our gratitude to Robert Koščal, Faculty of Science, for technical support. Our special thanks the five anonymous reviewers for their suggestions in both versions of the manuscript, which inspired us to present the obtained data in a much more appropriate form and greatly improve the manuscript.

Conflicts of Interest: The authors declare no conflict of interest.

\section{References}

1. Gorjanović-Kramberger, D. Geologijska prijegledna karta kraljevine Hrvatske-Slavonije. Tumač geologijskoj karti Zagreb (Zona 22, col. XIV). In Geologische Übersichtskarte des Königreiches Kroatien-Slavonien. Erläuterungen zur Geologischen Karte von Agram, Zone 22, Col XIV; Nakl. Kralj. Zemalj. Vlade, Odjel za Unut. Poslove: Zagreb, Croatia, 1908; p. 75, (In Croatian and German).

2. Babić, L.; Gušić, I.; Neděla-Devidé, D. Senonski kršnici na Medvednici i njihova krovina (Senonian breccias and overlying deposits on Mt. Medvednica-Northern Croatia). Geol. Vjesn. 1973, 25, 11-27, (In Croatian with English Summary).

3. Šikić, K.; Basch, O.; Šimunić, A. Basic Geological Map of Yugoslavia M 1:100,000, Sheet Zagreb L33-80; Croatian Geological Survey, Federal Geological Institute Belgrade: Zagreb, Croatia, 1977.

4. Crnjaković, M. Sedimentacija transgresivnog senona na južnim padinama Medvednice (Sedimentation of transgressive Senonian in Southern Mt. Medvednica). Geol. Vjesn. 1979, 32, 81-95, (In Croatian with English Summary).

5. Tari, V. Eoalpine (Cretaceous) tectonics in the Alpine/Pannonian transition zone. In Extensional Collapse of the Alpine Orogene and Hydrocarbon Prospects in the Basement and Basin Fill of the Western Pannonian Basin AAPG International Conference and Exhibition, Nice, France, Guidebook to Fieldtrip No. 6, Hungary; Horváth, F., Tari, G., Bokor, C., Eds.; American Association of Petroleum Geologists: Nice, France, 1995; pp. 133-155.

6. Marinčić, S.; Šparica, M.; Benić, J.; Korolija, B. Senonian sediments in the Mikulić Potok valley. In Geological Guide of Mt. Medvednica; Šikić, K., Ed.; Croatian Geological Institute-Croatian Geological Society, INA-Oil Industry: Zagreb, Croatia, 1995; pp. 73-76. (In Croatian)

7. Marinčić, S.; Šparica, M.; Benić, J. Upper Senonian deposits near Medvedgrad. In Geological Guide of Mt. Medvednica; Šikić, K., Ed.; Croatian Geological Institute-Croatian Geological Society, INA-Oil Industry: Zagreb, Croatia, 1995; pp. 85-87. (In Croatian)

8. Pavelić, D.; Sarkotić-Šlat, M.; Belak, M.; Jerinić, G. Stop 16. Senonian Red Beds. In Geological Guide of Mt. Medvednica; Šikić, K., Ed.; Croatian Geological Institute-Croatian Geological Society, INA-Oil Industry: Zagreb, Croatia, 1995; pp. 76-85. (In Croatian)

9. Crnjaković, M. Sedimentology of Cretaceous and Paleogene Clastics of Mt. Medvednica, Ivanščica, and Žumberak. Ph.D. Thesis, University of Zagreb, Zagreb, Croatia, 1987.

10. Kudrnovski, D. Sedimentološka Istraživanja Klastičnih Naslaga Senona Velikog Potoka na Južnim Padinama Medvednice. (Sedimentological Investigations of Senonian Clastic Deposits from Veliki Potok at Southern Slopes of Medvednica Mt.). Diploma Thesis, University of Zagreb, Zagreb, Croatia, 1993. (In Croatian)

11. Lužar-Oberiter, B. Provenance of Cretaceous Clastic Sediments from the Western Dinarides of Croatia. Ph.D. Thesis, University of Zagreb, Zagreb, Croatia, 2009. 
12. Tomljenović, B.; Csontos, L.; Márton, E.; Márton, P. Tectonic evolution of northwestern Internal Dinarides as constrained by structures and rotation of Medvednica Mountains, North Croatia. Geol. Soc. Lond. Spéc. Publ. V 2008, 298, 145-167. [CrossRef]

13. Beniest, A.; van Gelder, I.E.; Matenco, L.; Willingshofer, E.; Gruić, A.; Tomljenović, B. From orogenic buildup to extensional unroofing: The evolution of the Adria-Europe collisional zone in the Medvednica Mountains of Croatia. In Proceedings of the 11th Workshop on Alpine Geological Studies \& 7th European Symposium on Fossil Algae: Abstracts \& Field Guides, Schladming, Austria, 9-12 September 2013; Schuster, R., Ed.; Berichte der Geologischen Bundesanstalt: Wien, Austria, 2013; p. 94.

14. Pamić, J. The Sava-Vardar Zone of the Dinarides and Hellenides versus the Vardar Ocean. Eclogae Geol. Helv. 2002, 95, 99-113.

15. Schmid, S.M.; Bernoulli, D.; Fügenschuh, B.; Matenco, L.; Schefer, S.; Schuster, R.; Tischler, M.; Ustaszewski, K. The Alpine-Carpathian-Dinaridic orogenic system: Correlation and evolution of tectonic units. Swiss J. Geosci. 2008, 101, 139-183. [CrossRef]

16. Ustaszewski, K.; Kounov, A.; Schmid, S.M.; Schaltegger, U.; Krenn, E.; Frank, W.; Fügenschuh, B. Evolution of the Adria-Europe plate boundary in the northern Dinarides: From continent-continent collision to back-arc extension. Tectonics 2010. [CrossRef]

17. Matoš, B.; Vlahović, I.; Tomljenović, B.; Cvetković, M.; Saftić, B.; Pavelić, D.; Rukavina, D.; Kljajo, D.; Šajatović, B.; Murgić, M. Adriatic Carbonate Platform-Insights in External and Internal Dinaridic Units. In La Salle Fieldtrip Guidebook; Institut polytechnique LaSalle: Beauvais, France, 2016; p. 83.

18. Van Gelder, I.E.; Matenco, L.; Willingshofer, E.; Tomljenović, B.; Andriessen, P.A.M.; Ducea, M.N.; Beniest, A.; Gruić, A. The tectonic evolution of a critical segment of the Dinarides-Alps connection: Kinematic and geochronological inferences from the Medvednica Mountains, NE Croatia. Tectonics 2015, 34, 1952-1978. [CrossRef]

19. Lugović, B.; Šegvić, B.; Altherr, R. Petrology and tectonic significance of greenschists from the Medvednica Mts. (Sava unit, NW Croatia). Ofioliti 2006, 31, 39-50.

20. Basch, O. Geological map of Mt. Medvednica. In Geological Guide of Mt. Medvednica; Šikić, K., Ed.; Croatian Geological Institute-Croatian Geological Society, INA-Oil Industry: Zagreb, Croatia, 1995. (In Croatian)

21. Tomljenović, B. Structural Characteristics of Medvednica and Samoborsko Gorje Mountains. Ph.D. Thesis, University of Zagreb, Zagreb, Croatia, 2002.

22. Borojević Šostarić, S.; Neubauer, F.; Handler, R.; Palinkaš, L.A. Tectonothermal history of the basement rocks within the NW Dinarides: New 40Ar/39Ar ages and synthesis. Geol. Carpathica 2012, 63, 441-452. [CrossRef]

23. Belak, M.; Pamić, J.; Kolar-Jurkovšek, T.; Peckay, Z.; Karan, D. Alpinski regionalno-metamorfni kompleks Medvednice (sjeverozapadna Hrvatska) (Alpine regional metamorphic complex of the Medvednica Mt., NW Croatia). In Proceedings of the 1st Croatian Geological Congress, Opatija, Croatia, 18-21 October 1995; Vlahović, I., Velić, I., Šparica, M., Eds.; Institut za Geološka Istraživanja, Hrvatsko Geološko Društvo: Zagreb, Croatia, 1995; pp. 67-70. (In Croatian)

24. Belak, M.; Jamičić, D.; Crnko, J.; Sremac, J. Low-grade metamorphic rocks in lower part of the Bliznec creek (In Croatian). In Geological Guide of Mt. Medvednica; Šikić, K., Ed.; Institut za Geološka Istraživanja-Hrvatsko Geološko Društvo, INA—Industrija Nafte: Zagreb, Croatia, 1995; pp. 97-102.

25. Judik, K.; Balogh, K.; Tibljaš, D.; Árkai, P. New age data on the low-temperature regional metamorphism of Mt. Medvednica (Croatia). Acta Geol. Hung. 2006, 49, 207-221. [CrossRef]

26. Judik, K.; Rantitsch, G.; Rainer, T.M.; Árkai, P.; Tomljenović, B. Alpine metamorphism of organic matter in metasedimentary rocks from Mt. Medvednica (Croatia). Swiss J. Geosci. 2008, 101, 605-616. [CrossRef]

27. Đurđanović, Ž. O paleozoiku i trijasu Medvednice (Zagrebačke gore) i područja Dvora na Uni na temelju konodonta (About the Paleozoic and the Triassic of Medvednica Mountain and the Area near Dvor na Uni on the basis of Conodonts). Geol. Vjesn. 1973, 25, 29-45, (In Croatian with English Summary).

28. Sremac, J.; Mihajlović-Pavlović, M. Graptolites of Mt. Medvednica (Zagrebačka gora). Rad Jugosl. Akad. Znan. Umjet. 1983, 404, 65-68.

29. Babić, L.; Hochuli, P.A.; Zupanič, J. The Jurassic ophiolitic mélange in the NE Dinarides: Dating, internal structure and geotectonic implications. Eclogae Geol. Helv. 2002, 95, 263-275.

30. Sremac, J.; Kudrnovski, D.; Velić, J.; Bošnjak, M.; Velić, I. Statistical analyses of Late Cretaceous clastic deposits from Mali Potok Creek (Medvednica Mt., Northern Croatia). In Proceedings of the 2nd Croatian Congress on Geomathematics and Geological Terminology, Zagreb, Croatia, 6 October 2018; pp. 87-93. 
31. Lužar-Oberiter, B.; Mikes, T.; Dunkl, I.; Babić, L.; von Eynatten, H. Provenance of Cretaceous synorogenic sediments from the NW Dinarides (Croatia). Swiss J. Geosci. 2012, 105, 377-399. [CrossRef]

32. Neděla-Devidé, D. Importance of Globotruncanids in reconstruction of stratigraphy in Yugoslavia. In Proceedings of the 2nd Geological Congress FNRJ, Sarajevo, Bosnia and Herzegovina, 8-14 September 1957; pp. 134-154.

33. Zingg, T. Beiträge zur Schotteranalyse. Min. Petrog. Mitt. Schweiz. 1935, 15, 39-140.

34. Mikrotax.org. Available online: www.microtax.org (accessed on 13 September 2018).

35. Premoli Silva, I.; Sliter, W.V. Practical manual of Cretaceous planktonic foraminifera. In International School on Planktonic Foraminifera 10 Course: Cretaceous; Premoli Silva, I., Rettori, R., Eds.; Dipartimento di Scienze della Terra, University of Perugia: Perugia, Italy, 2002; p. 462.

36. Premoli Silva, I.; Verga, D. Practical manual of Cretaceous planktonic foraminifera. In International School on Planktonic Foraminifera, 3rd Course: Cretaceous; Verga, D., Rettori, R., Eds.; Universities of Perugia and Milan, Tipografia Pontefelcino: Perugia, Italy, 2004; p. 283.

37. Pettijohn, F.J. Sedimentary Rocks, 2nd ed.; Harper \& Bros: New York, NY, USA, 1957; p. 718.

38. Tomljenović, B.; Csontos, L. Neogene-Quaternary structures in the border zone between Alps, Dinarides and Pannonian Basin (Hrvatsko zagorje and Karlovac Basins, Croatia). Int. J. Earth Sci. 2001, 90, 560-578. [CrossRef]

39. Neděla-Devidé, D. Nalazi globotrunkana u Medvednici, Zrinskoj gori, Boki Kotorskoj i okolici Budve (Sur la presence de genre Globotruncana dans la Medvednica, Zrinska gora, Boka kotorska et dans les environs de Budva). Geol. Vjesn. 1953, 5-7, 299-315, (In Croatian with Franch Summary).

40. Neděla-Devidé, D. O proučavanju krede na sjevernim padinama Medvednice (On the study of Cretaceous deposits on northern slopes of Medvednica). Ljetop. Jugosl. Akad. 1956, 61, 325-328. (In Croatian)

41. Hu, X.; Jansa, L.; Wang, C.; Sarti, M.; Bak, K.; Wagreich, M.; Michalik, J.; Soták, J. Upper Cretaceous oceanic red beds (CORBs) in the Tethys: Occurrences, lithofacies, age, and environments. Cretac. Res. 2005, 26, 3-20. [CrossRef]

42. Hardenbol, J.; Thierry, J.; Farley, M.B.; Jacquin, T.; de Graciansky, P.-C.; Vail, P.R. Mesozoic and Cenozoic sequence chronostratigraphic framework of European Basins. In Mesozoic and Cenozoic Sequence Stratigraphy of European Basins, Chart 5-Cretaceous Chronostratigraphy; de Graciansky, P.-C., Hardenbol, J., Jacquin, T., Vail, P.R., Eds.; SEPM Special Publication: Broken Arrow, OK, USA, 1998; pp. 3-13. ISBN 978-1-56576-043-1.

43. Ogg, J.G.; Hinnov, L.A. Chapter 27, Cretaceous. In The Geological Time Scale, 1st ed.; Gradstein, F.M., Ogg, J.G., Schmitz, M.D., Ogg, G.M., Eds.; Elsevier: Amsterdam, The Netherlands, 2012; pp. 793-853. ISBN 9780444594259.

44. International Commission on Stratigraphy. Available online: www.stratigraphy.org/ICSchart/ ChronostratChart2018-08.jpg (accessed on 13 September 2018).

45. Haq, B.U. Cretaceous eustasy revisited. Glob. Planet. Chang. 2014, 113, 44-58. [CrossRef]

46. Velić, J.; Kišić, K.; Krasić, D. The characteristics of the production and processing of oil and natural gas in Croatia from 2000 to 2014. Min. Geol. Pet. Eng. Bull. 2016, 69-112. [CrossRef]

47. Hernitz, Z.; Vrbanac, B.; Pavlović, Z. O Stupnju Istraženosti Hrvatskog Dijela Panonskoga Bazena. Lecture on the XXVIII Regular Annual Assembly of the Section of Geology, Geophysics and Geohemics of the Scientific Council for Oil; HAZU: Zagreb, Croati, 19 April 1997.

48. Velić, J. Geologija Ležišta Nafte I Plina. (Geology of Oil and Gas Reservoirs); University of Zagreb and Faculty of Mining, Geology and Petroleum Engineering: Zagreb, Croatia, 2007; p. 342. ISBN 978-953-6923-10-6.

49. Malvić, T.; Velić, J. Relations between effective thickness, gas production and porosity in heterogeneous reservoir: An example from the Molve Field, Croatian Pannonian Basin. Pet. Geosci. 2010, 16, 41-51. [CrossRef]

50. Zečević, M.; Velić, J.; Sremac, J.; Troskot-Čorbić, T.; Garašić, V. Significance of the Badenian petroleum source rocks from the Krndija Mt. Geol. Croat. 2010, 63, 225-239. [CrossRef]

51. Pandžić, J. Pretercijar Jugozapadnog Dijela Panonskog Bazena (Pre-Tertiary Rocks in Southwestern Part of the Pannonian Basin); INA-Naftaplin: Zagreb, Croatia, 1986; p. 123. (In Croatian)

52. Čanović, M.; Kemenci, R. Mezozoik Podine Panonskog Basena u Vojvodini. Stratigrafija I Facije, Magmatizam, Paleogeografija (The Mesozoic of the Pannonian Basin in Vojvodina (Yugoslavia). Stratigraphy and Facies, Magmatism, Paleogeography); Matica Srpska: Novi Sad, Serbia, 1988; p. 336.

53. Brix, F.; Schultz, O. Erdöl und Erdgas in Österreich; Naturhistorisches Museum Wien und F. Berger: Horn, Austria, 1980; p. 312. ISBN 3850280713. 
54. Aksin, V. Geologija Nafte (Petroleum Geology), 1st ed.; Naftagas, Rudarsko-geološki fakultet u Beogradu: Novi Sad, Serbia, 1967; p. 800. (In Serbian)

55. Barić, G.; Mesić, I.; Jungwirth, M.; Španić, D. Gas and gas condensate-field in the north-west of the Drava depression, Yugoslavia. In Generation, Accumulation and Production of Europe's Hydrocarbons; Special Publication of the European Association of Petroleum Geoscientists, 1; Spencer, A.M., Ed.; Oxford University Press: Oxford, UK, 1991; pp. 323-339. ISBN 978-0198542827.

56. Barić, G. Naftna Geokemija (Petroleum Geochemistry); INA Croatian Geological Institute-Croatian Geological Society, INA-Oil Industry: Zagreb, Croatia, 2006; p. 253. ISBN 953-7049-30-2. (In Croatian)

57. Troskot-Čorbić, T.; Velić, J.; Malvić, T. Comparison of the Middle Miocene and the Upper Miocene source rock formations in the Sava Depression (Pannonian Basin, Croatia). Geol. Croat. 2009, 62, 123-133. [CrossRef]

58. Barić, G.; Britvić, V.; Dragaš, M. Source rocks and hydrocarbon accumulations in the Mura depression, R. Croatia. Nafta 1996, 47, 25-34.

(C) 2018 by the authors. Licensee MDPI, Basel, Switzerland. This article is an open access article distributed under the terms and conditions of the Creative Commons Attribution (CC BY) license (http:/ / creativecommons.org/licenses/by/4.0/). 